\title{
Effects of Hydraulic Retention Time (HRT) on the Performance of a Pilot-Scale Trickling Filter System Treating Low-Strength Domestic Wastewater
}

\author{
Abdul Rehman ${ }^{1}$, Nasir Ayub ${ }^{1}$, Iffat Naz ${ }^{1,2}$, Irum Perveen ${ }^{1}$, Safia Ahmed $^{1 *}$ \\ ${ }^{1}$ Department of Microbiology, Quaid-i-Azam University, Islamabad, Pakistan \\ ${ }^{2}$ Department of Biology, Qassim University, Kingdom of Saudi Arabia
}

Received: 19 July 2018

Accepted: 16 October 2018

\begin{abstract}
Attached growth wastewater treatment systems are considered to be effective in developing countries due to their low energy, operational and maintenance costs. Thus the present study mainly focused on the treatment of domestic wastewater by a pilot-scale trickling filter system (TFs) installed in the natural environment at a residential area of Quaid-i-Azam University, Islamabad, Pakistan, and it was operated under three different hydraulic retention times (HRT), i.e., 24, 48 and 72 hrs. Furthermore, pilot-scale TFs showed significant efficiency regarding the removal of physico-chemical and microbiological parameters under different HRTs, i.e., 70.9 and $23.5 \%$ reduction in COD and EC contents, respectively, at HRT of 48 hrs., while significant removal of TDS (34\%), $\mathrm{SO}_{4}(37 \%), \mathrm{PO}_{4}(81.8 \%)$ and TN (66.6\%) were noticed during operation of the system after $72 \mathrm{hrs}$ of HRT. Likewise, a maximum of $86.4 \%, 82.5 \%$ and $83 \%$ decrease in total bacterial count were observed at HRT of 24,48 and $72 \mathrm{hrs}$, respectively. Finally, it was suggested that pilot-scale TFs have great potential to be transferred to field scale in the areas disconnected from a centralized treatment system for handling sewage of small communities in underdeveloped and developing countries.
\end{abstract}

Keywords: stone media pilot scale TFs, domestic wastewater, hydraulic retention time (HRT), pathogen removal, chemical oxygen demand (COD)

\section{Introduction}

Water is exceptionally vital for the life and sustainability of all living organisms, but today, due to

*e-mail: safiamrl@yahoo.com adverse climatic conditions, it is considered a threatened resource worldwide [1]. Humans can stay alive without food for a number of weeks but without water, one cannot survive for more than a week [2]. It is a significant component of life being used for agricultural, industrial, domestic, recreational and other routine activities. According to Alkhamisi and Ahmed [3], about 70\% of water is consumed in agricultural activities, $20 \%$ in 
industrial and $10 \%$ in residential, recreational and other daily events throughout the world. Due to misuse and mismanagement of such a precious resource, around 900 million people throughout the world have no access to drinking water reservoirs [4]. In developing countries like Pakistan, water availability levels declined from 1299 (1996-97) to $1100 \mathrm{~m}^{3}$ per capita in 2006, which was predicted to be $700 \mathrm{~m}^{3}$ per capita by the year 2025 . Furthermore, extreme food deficiency ( 70 million tons) is anticipated due to a predicted severe shortage of water reservoirs $(\sim 32 \%)$ by 2025 [5].

In both rural and urban areas of developing countries, the quality of drinking water is severely affected due to microbial contamination. However, different factors are involved in the deterioration of drinking water reservoirs, including leaked pipes and their associated contamination, recurrent water supply and superficial water tables due to endless anthropogenic activities [6-7]. In addition, the USEPA [8] reported that the torrential rains, pesticides, unprocessed wastewaters, littoral water contamination and oil leakage are exceedingly toxic for drinking water reservoirs in Pakistan. Heavy metals also lead to health associated problems if its value exceeds permissible limits [9]. Global water scarcity, its competition and the negative influences on human life and the associated environment call for the development of appropriate strategies in wastewater treatment and water management sections [3, 8]. On the other hand, water accessibility, appropriateness and sustainability cannot be achieved abruptly via a single step. It needs integrated actions through government policy of priority.

Different treatment technologies are used today to treat wastewater, including physical treatment systems (filtration, precipitation), chemical treatment systems (flocculation, adsorption, coagulation) and biological treatment systems (attached growth and suspended growth systems). In comparison with physical and chemical methods, biological treatment systems are gaining attention due to its cost-effectiveness, easy operation and eco-friendly nature [10]. Biological treatment processes can be classified into attached and suspended growth. In attached growth systems, filter media are packed in the reactors to provide surface for the attachment of microorganisms to form slimy biofilm, for enhancing microbial absorptions and reduce contaminant rates [11-12]. Trickling filters (TFs), moving bed biological contactors, rotating biological contactors and membrane bioreactors are examples of attached growth systems. Moreover, such technologies offer several advantages such as easy handling, lesser hydraulic retention time (HRT), resistance to environmental variants, dynamic biomass and enhanced capacity to mineralize toxic substances [13-15].

Several studies have been conducted to evaluate the performance of bioreactors, including the influence of operating characteristics and packing media [16] in treating domestic or low-strength wastewater. Different researchers have examined the effect of temperature and HRTs on the performance of attached growth systems while treating domestic sewage [14, 17-18]. When the temperature is high, the conversion rates of organic matters in TFs are also high, while at low temperature, more organic matter usually remains un-degraded as a result of slow hydrolysis of volatile solids at a given HRT [19-20]. Therefore, a longer HRT would be required in TFs in low-temperature conditions [21]. The present research study was designed to evaluate the effect of different HRTs, i.e., 24, 48 and $72 \mathrm{hrs}$ on the performance of stone media pilot scale TFs constructed in an open environment under natural conditions at residential area of Quaid-i-Azam University (QAU) Islamabad Pakistan, treating domestic wastewater. Generally, HRT has significant effects on the efficiency of wastewater treatment systems, but several other factors such as seasonal variations, temperature, precipitation, humidity, organic loading and flow rates are obvious considerations. The temperature of the environment was routinely checked during biological operation and it was in the range of $16-38^{\circ} \mathrm{C}$. This study will also help to determine and fix the most appropriate HRT for the treatment of wastewater through pilot scale TFs in future studies.

\section{Experimental Section}

\section{Experimental Setup Scheme}

The stone media pilot scale TF was installed in an open environment in a residential area of QAU Islamabad, Pakistan, as reported by Rasool et al. [22]. The system includes a primary sedimentation tank (PST) (diameter, $1.53 \mathrm{~m}$ and height, $1.37 \mathrm{~m}$ ) to carry about 2300 gallons $\left(8.7 \mathrm{~m}^{3}\right)$ of influent, followed by the main body of TFs made of concrete (diameter $1.53 \mathrm{~m}$ and height $1.68 \mathrm{~m}$, with total volume of $3.06 \mathrm{~m}^{3}$ ) to support the stones (average diameter of 4 inches or $0.1 \mathrm{~m}$ ) used as filter media for bacterial growth. A recirculation tank (RCT) having the same dimensions as that of PST was installed next to the main body. A rotating arm distributor (length, $1.28 \mathrm{~m}$ ) with numerous small pores was installed at the top of the main body of TFs to distribute wastewater uniformly over the surface of a filter bed. Electric pumps were connected to the wastewater distribution system through the polyvinylchloride (PVC) pipe system. To collect effluent and sludge, an underdrain system (diameter, $1.53 \mathrm{~m}$ and height, $0.46 \mathrm{~m}$ ) was present at the bottom of the TF component and the total gap between the TF component and underdrain system was about $0.46 \mathrm{~m}$ in order to facilitate the oxygenation process. The stone bed has a voidage space of $35 \%$. The schematic illustration of overall treatment units of pilot scale TFs is shown in Fig. 1.

This pilot-scale facility had the capacity to treat approximately $0.8 \mathrm{~m}^{3}$ (211.34 gallons) of wastewater 


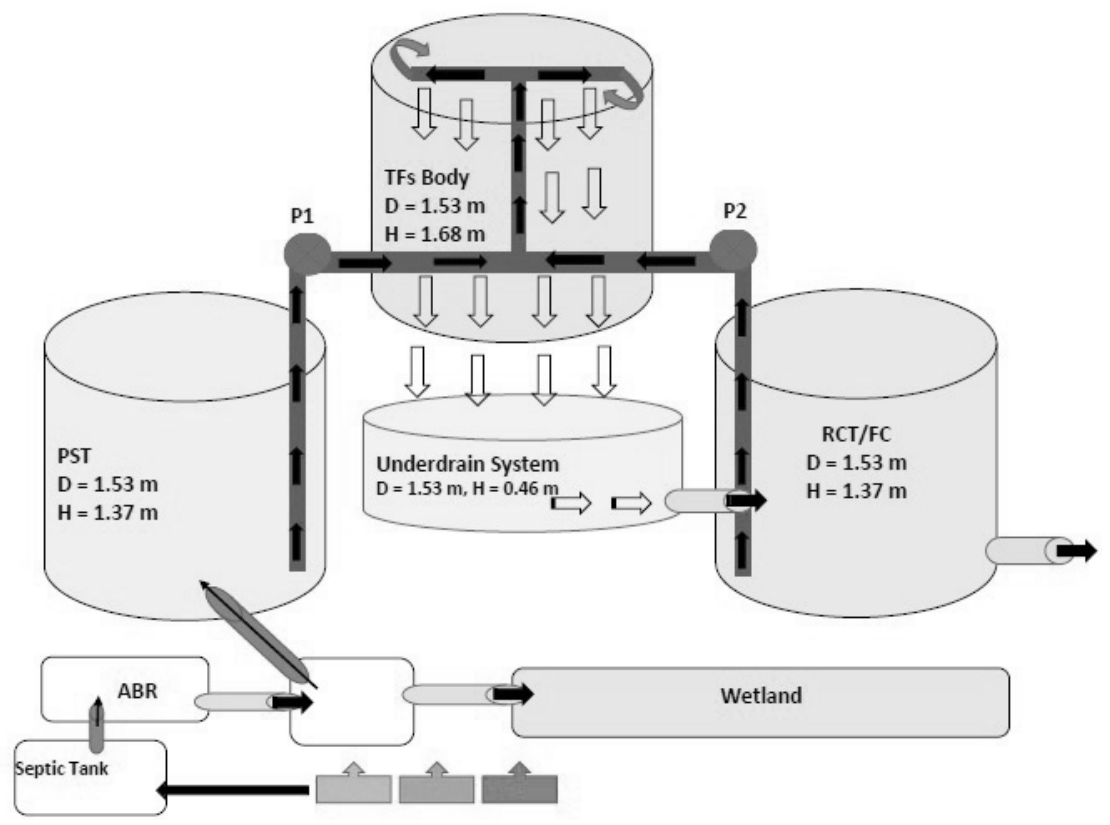

Fig. 1. Schematic illustration of overall treatment units of pilot-scale TFs.

depending upon the nature of flow rates maintained by both pumps. The study period covered the months from January 2016 to July 2016. For the development of active biofilter media, a mixture of wastewater and activated sludge (1:9) was pumped into the TFs for about 2 weeks before the start-up of the system for wastewater treatment. Environmental temperature was continuously monitored during the research study from January to July 2016, and it was in the range of $16-38^{\circ} \mathrm{C}$.

\section{Experimental Setup Operation}

The operation of pilot scale TFs was the same as reported by Rasool et al. [22], but in the current study, experiments were conducted in three different phases in order to determine the effect of HRTs $(24,48$ and $72 \mathrm{hrs}$ ) on the efficiency of pilot-scale TFs with respect to wastewater treatment. As pilot scale TFs contained two pumps (P1 installed on PST and P2 installed on RCT), initially influent was distributed for about $4.5 \mathrm{hrs}$ from PST to the top of filter bed through P1 at a hydraulic flow rate of $0.64 \mathrm{~m}^{3} / \mathrm{day}$, and after this $\mathrm{P} 1$ automatically switched off and pump P2 was turned on, which maintained the frequency of water distribution from RCT over the top of stone filter bed at a hydraulic flow rate of $0.04 \mathrm{~m}^{3} / \mathrm{day}$. But here in the $1^{\text {st }}$ phase of biological operation at HRT of $24 \mathrm{hrs}, \mathrm{P} 2$ continuously pumped and recirculated water from RCT for about $19.5 \mathrm{hrs}$ while in the $2^{\text {nd }}$ and $3^{\text {rd }}$ phases of biological operation at HRT of 48 and $72 \mathrm{hrs}, \mathrm{P} 2$ recirculated water for about 43.5 and $67.5 \mathrm{hrs,} \mathrm{respectively.} \mathrm{After}$ the completion of 24,48 and $72 \mathrm{hr}$ cycles, the effluent was allowed to flow into the sand bed compartment by gravitational force and then to be discharged into the adjacent fields or stream. After this, P2 was switched off automatically and it turned P1 on, which pumped a new sample of influent from the primary sedimentation tank to the reactor, and next cycle begins. The digitally controlled system had the capacity to evaluate its running time, so in case of any load shedding, each pump finalized its running time.

\section{Sampling of Wastewater}

Standard methods were followed for sampling during study [23]. Influent and effluent samples of 24, 48 and $72 \mathrm{hrs}$ HRT were collected in triplicate in $1000 \mathrm{~mL}$ separate clean plastic bottles and then shifted to the laboratory in an ice box in order to be preserved at $4^{\circ} \mathrm{C}$ in a refrigerator before determining changes in the concentration of different physicochemical and microbiological parameters.

\section{Microbiological Analysis of Influent and Effluent Samples}

Serial dilution and plate count method was used to determine colony forming units $(\mathrm{CFU} / \mathrm{mL})$ of aerobic bacteria according to standard methods [23]. Influent and effluent samples of 24,48 and $72 \mathrm{hr}$ HRT were collected, and dilutions $\left(10^{-1}, 10^{-3}, 10^{-5}\right.$ and $\left.10^{-7}\right)$ were plated on nutrient agar plates. After inoculation, agar plates were kept in an incubator at $37^{\circ} \mathrm{C}$ for $48 \mathrm{hrs}$ and then a number of bacterial colonies were counted by colony counter. $\mathrm{CFU} / \mathrm{mL}$ was then determined using the formula:

$$
\frac{\mathrm{CFU}}{\mathrm{mL}}=\frac{\text { No. of colonies } \mathrm{x} \text { Dilution factor }}{\text { Inoculum size }}
$$


Physicochemical Analysis of Influent and Effluent Samples

Physicochemical analysis of influent and effluent of 24, 48 and $72 \mathrm{hrs}$ HRT were carried out by determining different parameters, i.e., $\mathrm{pH}$ was determined using digital $\mathrm{pH}$ meters, while electrical conductivity (EC) was measured by a PCS multi-test meter. Chemical oxygen demand (COD) was determined by COD kits (Merck Chemicals Inc.) using a spectroquant Pharo 100 instrument according to manufacturer instructions [23]. Standard protocols $1540-\mathrm{C}, 4500-\mathrm{P}$ and 0375 barium chrometery were used to determine total dissolved solid (TDS), phosphate $\left(\mathrm{PO}_{4}\right)$ and sulphate $\left(\mathrm{SO}_{4}\right)$ concentrations in influent and effluent samples, while total nitrogen (TN) was determined by kit method using Merck kits [23].

\section{Results and Discussion}

\section{Pathogen Removal by Pilot Scale TFs under Different HRTs}

The use of raw wastewater for irrigation purposes is an approach to utilize domestic wastewater with considerable benefits such as being rich in nutrients that plants require for their growth and, moreover, it has the capability of increasing soil fertility instead of using fertilizers, which makes irrigation cost-effective [24]. Besides, sewage water also contains toxic compounds, heavy metals and highly pathogenic microorganisms that have extremely adverse effects on terrestrial and aquatic ecology, the environment and public health [2526]. A set of standard guidelines had been proposed by WHO [27] for the harmless use of treated water in agricultural sectors in order to secure agrarians and consumers of said crops. Therefore, it is essential to develop a suitable wastewater treatment technology in order to reduce the number of life-threatening and extremely pathogenic organisms before using treated effluent in agricultural lands. In the present study, it was observed that pilot-scale TFs showed significant efficiency under different HRTs for removing pathogenic organisms from wastewater $(p=0.0021)$. About $37-86.4 \%, 41.6-82.5 \%$ and $42.4-83 \%$ reduction in total bacterial count were observed at HRTs of 24, 48 and $72 \mathrm{hrs}$ respectively as shown in Fig. 2. The pattern of reduction in microbial count varied in different samples taken during the study period. The highest reduction (86.4\%) was observed in $\mathrm{S} 1$ at $24 \mathrm{hrs}$ HRT. While at $48 \mathrm{hrs}$ and $72 \mathrm{hrs}$ HRTs, the percentage reduction was lower in samples of low-temperature months (i.e., S1-S3), which was greater than $70 \%$ in samples of high-temperature months (i.e., S4, S5 and S6; Fig. 2). This pattern showed that environmental temperature also played a role in the pathogen reduction in the trickling filter [19-21]. The decrease in the number of pathogenic organisms within effluent samples might be due to the reduction of carbonaceous components in wastewater with treatment, or due to the confinement of microorganisms in the biofilm by adsorption [28]. Later on, it was associated with detachment and deactivation or natural die-off processes [29]. Furthermore, a similar percentage reduction $(80-87 \%)$ in microbial count at HRT of $48 \mathrm{hrs}$ were reported by Khan et al. [17] during their studies using a laboratory-scale stone media trickling filter system integrated with a sand column.

\section{Carbonaceous and Nitrogenous Pollutant Removal by Pilot-Scale TFs under Different HRTs}

Hydraulic retention time (HRT) is the time duration by soluble compounds to remain in a bioreactor for a specified period of time. It is directly related to the flow of wastewater toward a bioreactor [30]. Furthermore, adequate flow or recirculation rate and retention time offers sufficient contact between microbial biofilm and wastewater, resulting in an enhanced organic as well as nitrogenous pollutant removal efficiency of the treatment facility [30-31]. The effect of different HRTs on the performance of pilot-scale TFs are shown

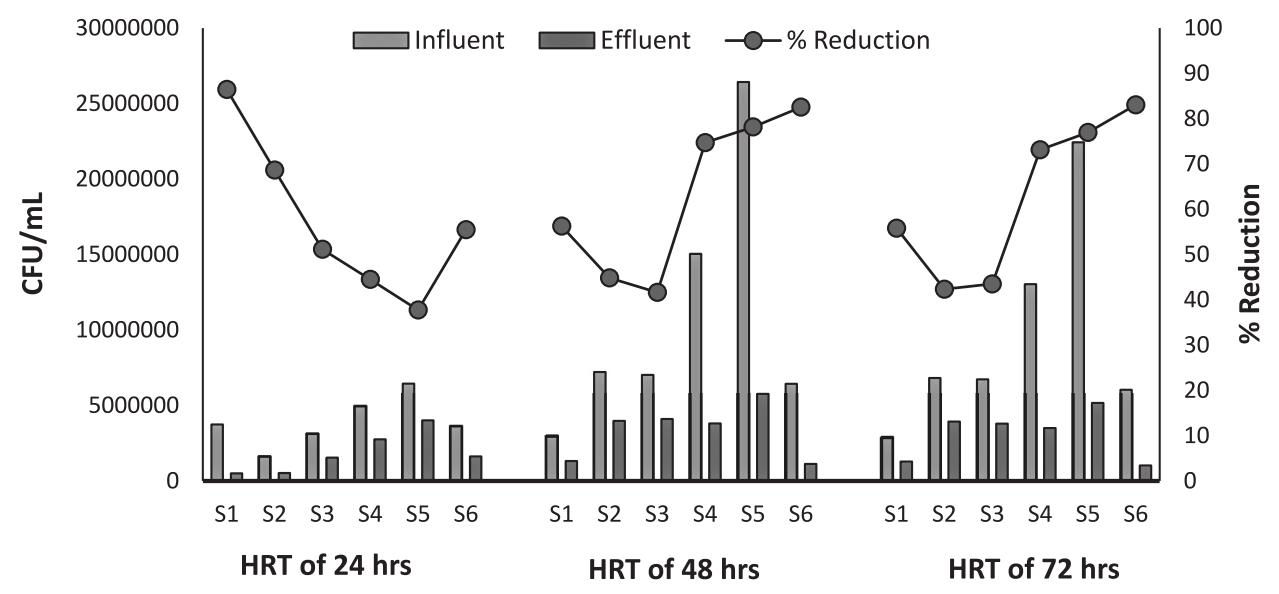

Fig. 2. Efficiency of pilot-scale TFs in terms of pathogen removal under different HRTs. 
in Table 1. It was observed that increased HRT (from $24 \mathrm{hrs}$ to $72 \mathrm{hrs}$ ) positively affected the efficiency of the system with respect to wastewater treatment. In the case of COD content reduction, the efficiency of pilotscale TFs under an HRT of $24 \mathrm{hrs}$ were in the range of $59.7-84.6 \%$ while at HRT of 48 and $72 \mathrm{hrs}$ they were in the range of $62.2-85.3 \%$ and $23.5-80.8 \%$ respectively $(p=0.003)$, as shown in Fig. 3. This agreed with the findings of Ladu et al. [32], who studied the effects of three different HRTs on the efficiency of anaerobic filters while treating domestic wastewater, and found that the efficiency of the reactor increased by increasing HRT (from one to three days). Furthermore, they observed a $32 \%$ reduction in COD values at HRT of one day, $40 \%$ at HRT of two days and $44 \%$ at HRT of three days. The maximum removal percentage of COD at higher HRT might be due to continuous recirculation of wastewater as a result microorganisms present in slime layer actively oxidizing organic compounds present in wastewater [14]. Moreover, Laing [33] reported an $84 \%$ reduction in COD values at HRT of $24 \mathrm{hrs}$ while using sequential anaerobic batch reactors to treat synthetic winery wastewater. Leyva-Díaz et al. [34] reported an $85 \%$ reduction in COD contents at HRT of $18 \mathrm{hrs}$ during their studies while using a hybrid moving bed membrane bioreactor.

In the current study, it was observed that the TDS removal efficiency of pilot-scale TFs increased with increases of HRT. About a $22 \%$ maximum reduction in TDS level was observed at HRT of $24 \mathrm{hrs}$ while 38.8 and $57.8 \%$ reductions were found in TDS levels at HRT of 48 and 72 hrs, respectively ( $p=0.008)$, as shown in Fig. 3 .
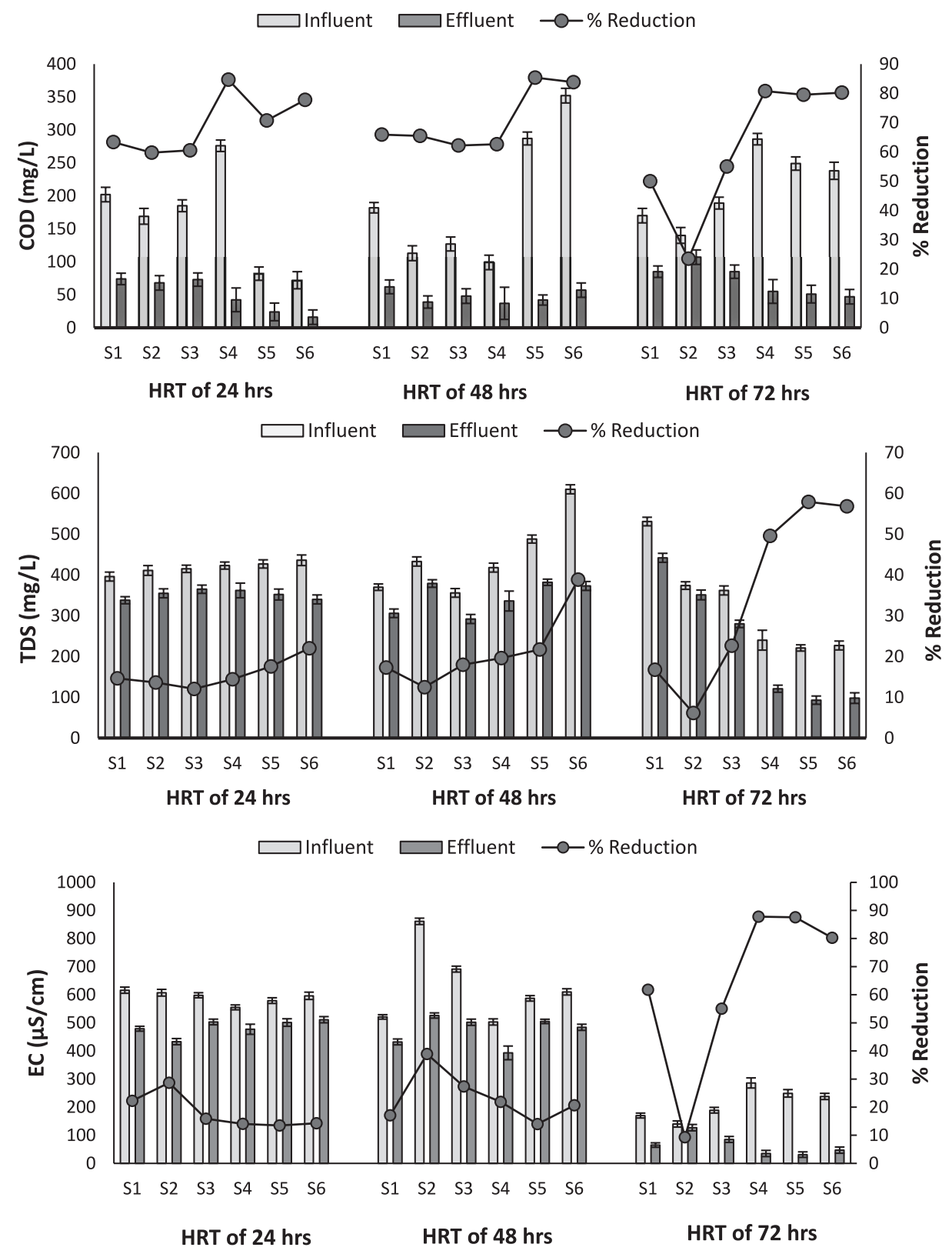

Fig. 3. Efficiency of pilot-scale TBF system in the average reduction of COD, TDS and EC values under different HRTs (bar indicates SD). 
The reduction in TDS contents with increasing HRT was also due to continuous recirculation of wastewater for an extended period of time; as a result, microorganisms within biofilm got sufficient time to degrade dissolved organic components [18, 35]. Furthermore, Khan et al. [17] reported $23 \%$ and $66 \%$ reduction in the TDS values at HRT of $24 \mathrm{hrs}$ and $48 \mathrm{hrs}$, respectively, during their study using stone media TFs integrated with sand column filter. According to WHO [27], the approved range of EC in wastewater is $400-1500 \mu \mathrm{S} / \mathrm{cm}$, and furthermore it has a direct relationship with TDS, COD and fluorides present in water samples. Moreover, it was found that EC values of wastewater decreased up to $13.4-28.6 \%$ at HRT of $24 \mathrm{hrs}$ while $14-39 \%$ and $5.87-23.04 \%$ reduction were observed at HRT of 48 and $72 \mathrm{hrs}$, respectively ( $p=0.03$ ), as shown in Fig. 3. A basic reason for the reduction in EC content might be that ammonium, nitrates and nitrites present in wastewater were converted to molecular nitrogen [22]. As a result, the concentration of free ions was reduced in order to conduct electrical current. Khan et al. [17] also reported a significant reduction in EC values by increasing HRT from 24-48 hrs while using a laboratory-scale fixed biofilm reactor.

Phosphate $\left(\mathrm{PO}_{4}\right)$ in domestic wastewater came in the form of polyphosphates, causing eutrophication in water bodies leading to adverse effects on aquatic life by minimizing light penetration (hypoxia) and dissolved oxygen (DO) concentrations [14, 17]. Moreover, detergents, soaps, shampoos, oil and grease are being considered the most prominent source for $\mathrm{PO}_{4}$ contamination in domestic wastewater [36]. In the present study, it was observed that an average reduction of $44.12 \%, 40.77 \%$ and $82 \%$ were achieved in $\mathrm{PO}_{4}$ concentrations at HRT of 24, 48 and $72 \mathrm{hrs}$, respectively (for an overview, see Table 2). However, the overall efficiency of pilot-scale TFs in the reduction of $\mathrm{PO}_{4}$ concentration is shown in Fig. 4, where individually up to $88.8 \%, 79.7 \%$ and $96.3 \%$ reduction were observed at HRTs of 24, 48 and $72 \mathrm{hrs,} \mathrm{respectively,} \mathrm{which} \mathrm{was}$ statistically highly significant $(p=0.007)$. These results showed consistency and compatibility with previous research work, where about $80-97 \%$ reduction in $\mathrm{PO}_{4}$ concentrations were observed using "submerged membrane reactor" and "combined upflow anaerobic fixed bed in combination with suspended aerobic reactor having membrane unit" [36]. Khan et al. [17] showed an average reduction of $23 \%$ and $38 \%$ at HRT of 24 and $48 \mathrm{hrs}$, respectively, in $\mathrm{PO}_{4}$ level using laboratoryscale stone media TFs to treat domestic wastewater and concluded that the removal of $\mathrm{PO}_{4}$ was associated with metabolic activities of the microbial community flourishing on filter media. Furthermore, Zeng et al. [37] reported that nitrification and denitrification processes had promising effects on $\mathrm{PO}_{4}$ elimination from wastewater during biological treatment.
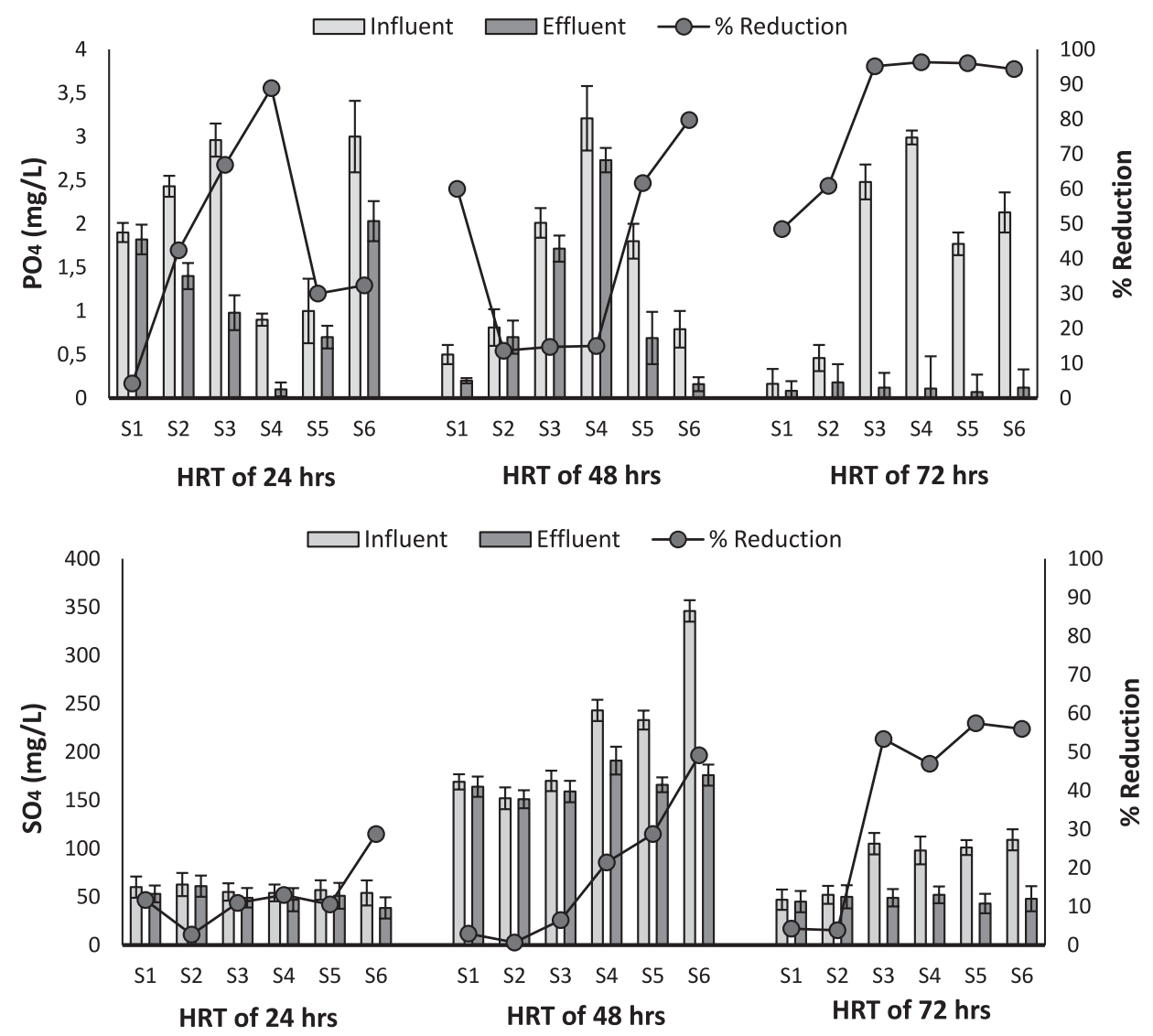

Fig. 4. Efficiency of pilot-scale TBF system in the average reduction of $\mathrm{PO}_{4}$ and $\mathrm{SO}_{4}$ content under different HRTs (bar indicates SD). 
In the present study, the efficiency of the pilotscale TFs to remove sulphates $\left(\mathrm{SO}_{4}\right)$ from wastewater increased with increases of HRT from 24-72 hrs. It was observed that during the $1^{\text {st }}$ phase of biological operation, an average reduction of $12.9 \%$ whereas $18.2 \%$ and $36.96 \%$ reduction in $\mathrm{SO}_{4}$ concentration were observed during the $2^{\text {nd }}$ and $3^{\text {rd }}$ phases of biological operations with respect to HRTs as shown in Table 2. However, the overall efficiency of pilot scale TFs in the reduction of $\mathrm{SO}_{4}$ concentration is shown in Fig. 4, where significant $(p=0.006)$ reductions were observed in $\mathrm{SO}_{4}$ content. Higher removal efficiency of $\mathrm{SO}_{4}$ would be related to continuous recirculation and extended treatment time and, furthermore, higher HRT provides a favorable environment for sulphate-oxidizing bacteria because $\mathrm{SO}_{4}$ become oxidized in the presence of oxygen [34]. Ehlers and Turner [38] reported that sulphate-oxidizing bacteria oxidize the sulphur to sulphates, which were then reduced to sulphide by sulphate-reducing bacteria. Sulphate-oxidizing bacteria were widely detected in domestic sewage and played a significant role in carbon, sulphur and nitrogen cycles. Laing et al. [33] reported that anoxic conditions developed within the biofilm reactor with the passage of time, and as a result sulphurreducing bacteria actively participate in the reduction of sulphur compounds.

The $\mathrm{pH}$ value variations in the influent and effluent samples were monitored over time and it was observed in the range of $6.3-7.5,6.8-8.5$ and 7.1-8.2 during the $1^{\text {st }}, 2^{\text {nd }}$ and $3^{\text {rd }}$ phases of biological operation ( $p=0.01)$ under different HRTs (i.e., 24, 48 and $72 \mathrm{hrs,}$ respectively; Fig. 5). According to WHO [27] and the USEPA [39], the rate of ammonium oxidation decreased significantly in acidic $\mathrm{pH}$ range. Consequently, for optimum performance of treatment systems, it is best to maintain $\mathrm{pH}$ in the range of $6.8-8.0$. The outcomes of a study in this regard revealed the same range indicating pilot scale TFs as one of the best options for domestic wastewater treatment. Likewise, Khan et al. [17] reported the equivalent $\mathrm{pH}$ range and its alteration with redox as well as nitrification and denitrification reactions and, furthermore, described that the $\mathrm{pH}$ values diminution after treatment through pilot-scale TFs might be due to the denitrification phenomenon converting nitrates to molecular nitrogen.

Untreated domestic wastewater contains a large amount of nitrogen either in organic or inorganic forms such as ammonia, nitrates and nitrites [40]. Therefore, total nitrogen (TN) refers to the total amount of organic and inorganic fractions of nitrogen present in wastewater, while the term Kjeldahl nitrogen refers to the sum of organic and inorganic fractions of nitrogen from ammonium $\left(\mathrm{NH}_{4}^{+}\right)$[22]. The principle sources of $\mathrm{TN}$ in domestic wastewater are urea and proteins. Although it is an important component required for the growth of microorganisms and plants, the excess
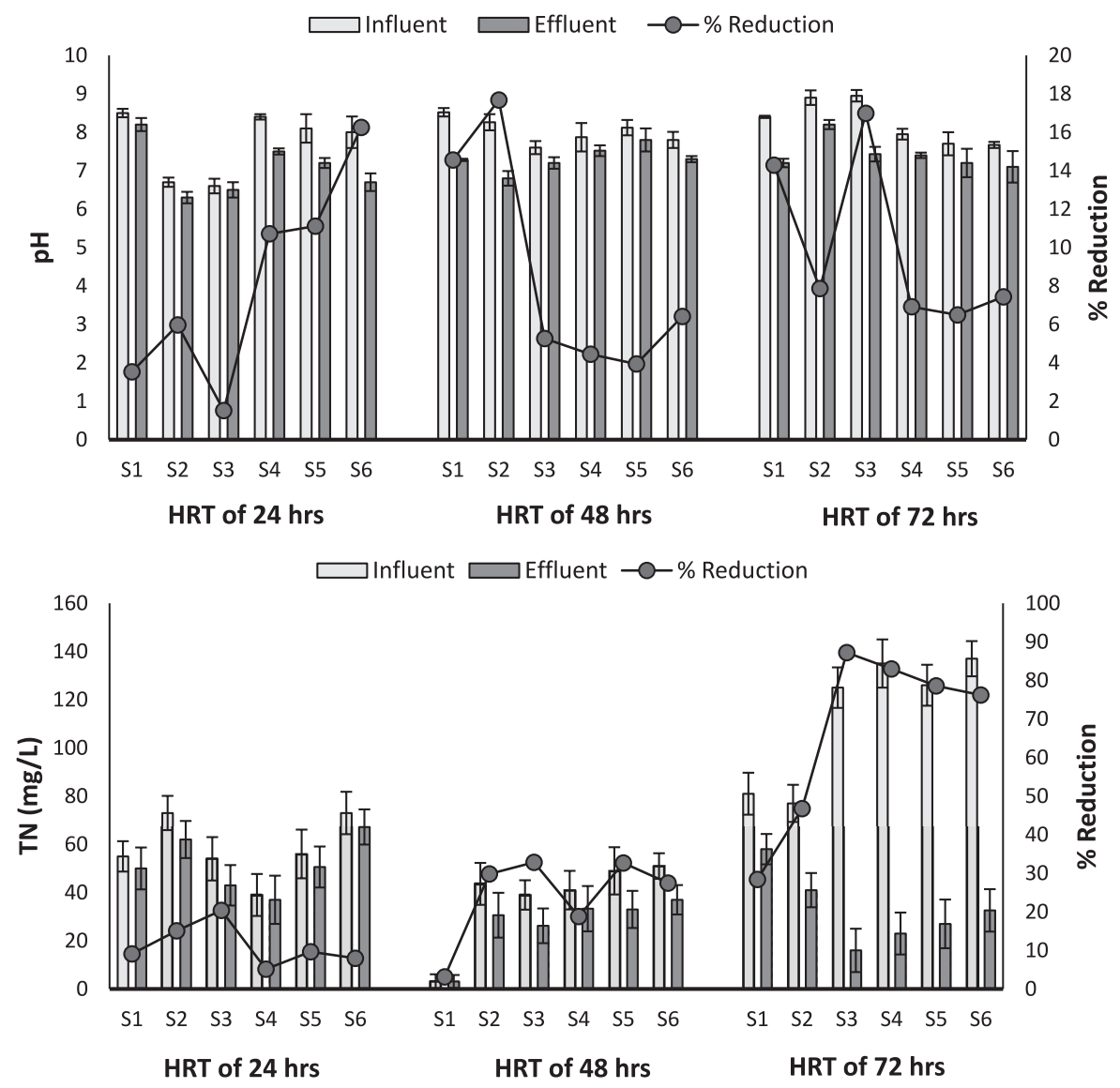

Fig. 5. Efficiency of pilot-scale TBF system in the average reduction of $\mathrm{pH}$ and TN content under different HRTs (bar indicates SD). 


\begin{tabular}{|c|c|c|c|c|c|c|c|c|c|c|c|c|c|c|c|c|c|c|c|c|c|c|}
\hline \multirow{3}{*}{$\mathscr{\infty}$} & 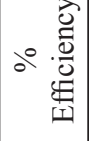 & 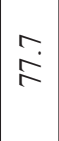 & $\begin{array}{l}\text { Oे } \\
\stackrel{d}{d}\end{array}$ & $\mid \begin{array}{l}0 \\
\stackrel{9}{1} \\
\dot{I}\end{array}$ & 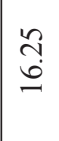 & $\mid \begin{array}{c}\tilde{n} \\
i \\
\tilde{m}\end{array}$ & $\mid \begin{array}{c}t \\
\text { d } \\
\stackrel{d}{d}\end{array}$ & $\stackrel{n}{r}$ & $\begin{array}{l}\infty \\
\infty \\
\infty\end{array}$ & $\left|\begin{array}{l}\infty \\
\infty \\
\infty \\
\infty \\
\infty\end{array}\right|$ & $\begin{array}{l}0 \\
0 \\
0 \\
i\end{array} \mid$ & $\vec{\nabla}$ & $\mid \begin{array}{l}n \\
\stackrel{2}{2} \\
2\end{array}$ & $\mid \begin{array}{l}m \\
\vec{g}\end{array}$ & 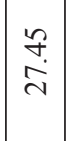 & 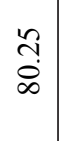 & 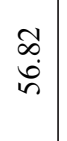 & $\stackrel{\stackrel{n}{g}}{=}$ & $\stackrel{?}{\sim}$ & 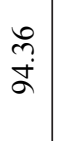 & \begin{tabular}{l}
0 \\
\multirow{n}{n}{} \\
n.
\end{tabular} & 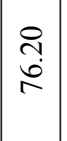 \\
\hline & 피 & 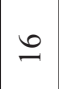 & 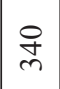 & $\bar{n}$ & $\overline{6}$ & $\begin{array}{l}\tilde{\sigma} \\
\dot{i}\end{array}$ & $\begin{array}{c}\infty \\
+ \\
\infty \\
\infty \\
n\end{array}$ & $\frac{1}{\tilde{b}}$ & in & $\stackrel{m}{m}$ & $\begin{array}{c}+ \\
+ \\
+\end{array}$ & $\stackrel{?}{r}$ & $\begin{array}{l}0 \\
0 \\
0\end{array}$ & $\begin{array}{l}0 \\
0 \\
I\end{array}$ & $\begin{array}{l}0 \\
\dot{m} \\
\end{array}$ & f & $\stackrel{\infty}{\sigma}$ & \&্ల & $\vec{r}$ & $\stackrel{1}{\circ}$ & $\stackrel{\infty}{+}$ & $\begin{array}{c}0 \\
i \\
i \\
m\end{array}$ \\
\hline & - & $\approx$ & $\begin{array}{l}0 \\
⿱ 亠 䒑 \\
\end{array}$ & in & $\stackrel{0}{\infty}$ & $\ddot{m}$ & 品 & $\stackrel{0}{\stackrel{r}{r}}$ & $\tilde{\approx}$ & $\frac{0}{6}$ & $\frac{0}{6}$ & $\stackrel{\infty}{\sim}$ & $\begin{array}{l}\hat{\imath} \\
\dot{0}\end{array}$ & $\left|\begin{array}{l}0 \\
\dot{f} \\
\dot{f}\end{array}\right|$ & $\frac{0}{\dot{m}}$ & $\underset{\sim}{\sim}$ & $\widehat{\AA}$ & ले & $\begin{array}{l}\hat{b} \\
i\end{array}$ & $\stackrel{m}{\vec{i}}$ & $\stackrel{\circ}{\circ}$ & $\hat{m}$ \\
\hline \multirow{3}{*}{$\tilde{n}$} & 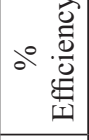 & $\ddot{\dot{R}}$ & 点 & $\ddot{n}$ & $\exists$ & $\dot{m}$ & $\begin{array}{l}n \\
n \\
0 \\
0\end{array}$ & \begin{tabular}{l}
$t$ \\
\multirow{\sigma}{*}{} \\
$\sigma$
\end{tabular} & $\begin{array}{c}n \\
\vdots \\
\infty\end{array}$ & $\stackrel{\vec{\lambda}}{\vec{\lambda}}$ & $\mid \begin{array}{l}\stackrel{+}{ \pm} \\
\end{array}$ & $\begin{array}{l} \pm \\
\dot{m} \\
\dot{m}\end{array}$ & $\left|\begin{array}{l}0 \\
: \\
\dot{\sigma}\end{array}\right|$ & $\left|\begin{array}{c}n \\
0 \\
0 \\
i\end{array}\right|$ & $\left|\begin{array}{l}n \\
0 \\
i \\
n\end{array}\right|$ & \begin{tabular}{l}
$\tilde{y}$ \\
\multirow{\infty}{\infty}{} \\
$\infty$
\end{tabular} & $\begin{array}{l}\vec{a} \\
\hat{i}\end{array}$ & $\begin{array}{l}\stackrel{\bullet}{ \pm} \\
\stackrel{ \pm}{ \pm}\end{array}$ & 守 & $\begin{array}{l}2 \\
\dot{\delta} \\
o\end{array}$ & $\underset{\substack{f \\
\text { i }}}{ }$ & $\begin{array}{c}\tilde{n} \\
\infty \\
\infty\end{array}$ \\
\hline & 디 & $\stackrel{ \pm}{\sim}$ & 命 & $\vec{i}$ & $\stackrel{2}{\sim}$ & $\ddot{0}$ & $\frac{0}{i n}$ & $\begin{array}{l}0 \\
\dot{0} \\
i\end{array}$ & F & $\begin{array}{c}\tilde{D} \\
ల \\
ల\end{array}$ & 咢 & $\stackrel{\infty}{\sim}$ & $\begin{array}{l}0 \\
0 \\
0\end{array}$ & $\mid \begin{array}{l}0 \\
0 \\
0 \\
0\end{array}$ & $\stackrel{0}{\dot{m}}$ & $\bar{n}$ & $\kappa$ & oి & $\stackrel{2}{\sim}$ & $\stackrel{5}{\circ}$ & $\mathscr{F}$ & $\widehat{\imath}$ \\
\hline & - & $\infty$ & $\widehat{\mathcal{F}}$ & in & $\vec{\infty}$ & $\stackrel{\circ}{-}$ & 立 & $\begin{array}{l}0 \\
\dot{0} \\
i n\end{array}$ & $\underset{\infty}{\infty}$ & $\mid \begin{array}{l}\infty \\
\stackrel{\infty}{+}\end{array}$ & $\mid \begin{array}{c}\infty \\
i n\end{array}$ & $\begin{array}{c}\simeq \\
\infty\end{array}$ & $\stackrel{\infty}{-}$ & $\begin{array}{l}0 \\
\dot{\vec{n}} \\
\vec{v}\end{array}$ & $\begin{array}{l}0 \\
\dot{q}\end{array}$ & $\stackrel{g}{d}$ & $\overrightarrow{\mathrm{N}}$ & 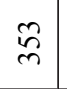 & $\grave{i}$ & $\stackrel{尺}{-}$ & 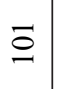 & 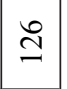 \\
\hline \multirow{3}{*}{ W } & 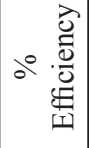 & $\begin{array}{l}0 \\
\dot{+} \\
\infty\end{array}$ & $\underset{\mathcal{F}}{\stackrel{\mathcal{I}}{ \pm}}$ & $\begin{array}{l}n \\
o \\
\dot{\Xi}\end{array}$ & $\hat{\varrho}$ & $\begin{array}{l}\infty \\
\infty \\
\infty \\
\infty\end{array}$ & $\begin{array}{l}\stackrel{2}{2} \\
\grave{I}\end{array}$ & $\stackrel{m}{\vec{n}}$ & $\begin{array}{l}0 \\
\mathbb{i}\end{array}$ & $\begin{array}{l}0 \\
\stackrel{9}{9}\end{array}$ & $\left|\begin{array}{l}0 \\
\infty \\
\dot{\lambda} \\
\mid\end{array}\right|$ & $\begin{array}{l}\dot{J} \\
\dot{*}\end{array}$ & $\left|\begin{array}{l}n \\
\alpha \\
\dot{y}\end{array}\right|$ & $\stackrel{+}{\dot{\sim}}$ & $\left|\begin{array}{l}\infty \\
\stackrel{0}{\infty} \\
\infty\end{array}\right|$ & $\stackrel{0}{\stackrel{8}{\infty}}$ & $\begin{array}{l}\infty \\
2 \\
2 \\
\sigma \\
q\end{array}$ & 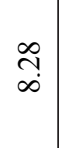 & $\vec{\sigma}$ & స̂. & $\begin{array}{l}\tilde{\hat{o}} \\
\dot{\sigma}\end{array}$ & $\begin{array}{l}\text { ¿े } \\
\text { i }\end{array}$ \\
\hline & 디 & $\stackrel{F}{f}$ & $\begin{array}{l}\mathbb{S} \\
\text { r }\end{array}$ & 礻 & 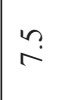 & $\overrightarrow{0}$ & $\begin{array}{l}\stackrel{\dot{P}}{f} \\
\vec{f}\end{array}$ & $\stackrel{0}{\dot{m}}$ & $\hat{n}$ & $\begin{array}{l}\infty \\
m \\
m\end{array}$ & $\tilde{m}$ & 色 & 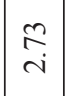 & $\begin{array}{l}0 \\
\dot{\Xi}\end{array}$ & $\stackrel{m}{m}$ & $i n$ & $\vec{\beth}$ & $\stackrel{\circ}{m}$ & $\stackrel{\leftrightarrow}{\stackrel{r}{*}}$ & $\overline{0}$ & $\approx$ & 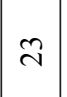 \\
\hline & - & $\stackrel{0}{\sim}$ & $\tilde{\vartheta}$ & 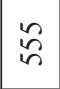 & $\begin{array}{c}+ \\
\infty\end{array}$ & $\hat{o}$ & $\begin{array}{l}0 \\
\dot{n} \\
\dot{n}\end{array}$ & $\begin{array}{l}0 \\
\dot{m}\end{array}$ & ๙ & $\stackrel{\infty}{\ngtr}$ & $\begin{array}{l}m \\
\tilde{n}\end{array}$ & \begin{tabular}{l|}
$\hat{\infty}$ \\
$\stackrel{\infty}{\sim}$ \\
\end{tabular} & \begin{tabular}{|l}
$\vec{r}$ \\
$\tilde{n}$
\end{tabular} & \begin{tabular}{|c|}
$\stackrel{\dot{J}}{\sim}$ \\
$\stackrel{\sim}{v}$
\end{tabular} & $\underset{\dot{F}}{\stackrel{O}{*}}$ & $\underset{\sim}{\infty}$ & $\underset{i}{\stackrel{9}{i}}$ & $\begin{array}{l}\infty \\
\infty\end{array}$ & $\begin{array}{l}n \\
\\
\end{array}$ & बे & $\stackrel{\infty}{\circ}$ & $\stackrel{n}{n}$ \\
\hline \multirow{3}{*}{$\tilde{n}$} & 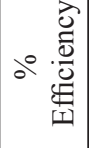 & $\begin{array}{l}n \\
8 \\
8\end{array}$ & $\begin{array}{l}n \\
o \\
i \\
d\end{array}$ & $\begin{array}{l}\infty \\
\infty \\
\\
\end{array}$ & $\stackrel{\sim}{\rightarrow}$ & $\mid \begin{array}{l}\hat{\alpha} \\
\dot{\delta}\end{array}$ & $\stackrel{\circ}{=}$ & $\begin{array}{l}\hat{n} \\
\dot{\sim}\end{array}$ & $\begin{array}{l}\tilde{I} \\
\tilde{S}\end{array}$ & $\mid \begin{array}{l}\dot{0} \\
\dot{\infty}\end{array}$ & 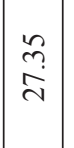 & $\mid \begin{array}{l}0 \\
i \\
i n\end{array}$ & $\begin{array}{l}\mathbf{6} \\
\pm \\
\end{array} \mid$ & f̊. & $\left|\begin{array}{l}\tilde{N} \\
\tilde{j} \\
\tilde{\omega}\end{array}\right|$ & $\begin{array}{l}\delta \\
\text { s. } \\
\text { in }\end{array}$ & $\begin{array}{l}n \\
\tilde{d} \\
i\end{array}$ & $\begin{array}{l}\dot{0} \\
\ddot{\lambda}\end{array}$ & $\mid$\begin{tabular}{l}
$\infty$ \\
\multirow{2}{0}{} \\
0
\end{tabular} & $\begin{array}{l}\text { - } \\
\text { nू }\end{array}$ & $\begin{array}{l}m \\
m \\
\hat{n}\end{array}$ & $\stackrel{2}{\infty}$ \\
\hline & 디 & $\approx$ & $\begin{array}{l}2 \\
\tilde{n} \\
m\end{array}$ & 总 & 每 & $\begin{array}{l}\infty \\
\stackrel{0}{0}\end{array}$ & $\begin{array}{l}\dot{g} \\
\dot{q}\end{array}$ & $\begin{array}{l}\dot{P} \\
\dot{q}\end{array}$ & $\stackrel{\infty}{+}$ & $\tilde{\mathrm{Z}}$ & 苚 & $\stackrel{-1}{\sim}$ & $\stackrel{\mathbb{S}}{\underset{I}{-}}$ & $\stackrel{0}{\circ}$ & ชู & $\infty$ & $\underset{\sim}{\stackrel{\sim}{\sim}}$ & 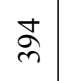 & $\stackrel{?}{\stackrel{?}{r}}$ & $\stackrel{7}{\circ}$ & $\vec{q}$ & $\stackrel{0}{0}$ \\
\hline & - & $\stackrel{\infty}{\infty}$ & $\stackrel{n}{\gamma}$ & $\begin{array}{l}\infty \\
i \\
i n\end{array}$ & : & 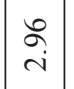 & $\begin{array}{c}0 \\
\dot{n} \\
i\end{array}$ & $\begin{array}{l}0 \\
\dot{n}\end{array}$ & $\widehat{\cong}$ & $\begin{array}{l}0 \\
n \\
n\end{array}$ & $\vec{\sigma}$ & $\begin{array}{l}0 \\
- \\
\end{array}$ & 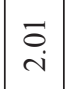 & $\begin{array}{l}0 \\
\stackrel{8}{I} \\
-\end{array}$ & 官 & $\stackrel{\infty}{\infty}$ & $\begin{array}{l}\mathbf{d} \\
\text { r }\end{array}$ & $\stackrel{\sim}{n}$ & $\begin{array}{l}n \\
\vdots \\
\infty\end{array}$ & $\stackrel{\infty}{\stackrel{i}{i}}$ & $\stackrel{c}{\varrho}$ & $\cong$ \\
\hline \multirow{3}{*}{$\tilde{N}$} & ○。 & $\begin{array}{l}\infty \\
\dot{a} \\
\dot{a}\end{array}$ & $\begin{array}{l}3 \\
\dot{2} \\
\dot{2}\end{array}$ & 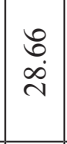 & $\begin{array}{l}\hat{a} \\
\dot{i}\end{array}$ & $\left|\begin{array}{c}\infty \\
\tilde{n} \\
\mathcal{Y}\end{array}\right|$ & $\vec{i}$ & $\begin{array}{l}8 \\
\dot{1} \\
\end{array}$ & $\begin{array}{l}n \\
3 \\
3\end{array}$ & $\stackrel{n}{\mathfrak{I}}$ & $\begin{array}{l}\dot{P} \\
\dot{q}\end{array}$ & $\mid \begin{array}{l}1 \\
\vdots \\
\Xi\end{array}$ & $\mid \begin{array}{l}0 \\
\ddot{g}\end{array}$ & $\begin{array}{l}0 \\
0 \\
0\end{array}$ & $\left|\begin{array}{l}\tilde{D} \\
\grave{\lambda}\end{array}\right|$ & $\begin{array}{l}\tilde{n} \\
\tilde{n}\end{array}$ & $\underset{0}{ \pm}$ & $\begin{array}{c}\hat{\infty} \\
\dot{\infty} \\
\dot{n}\end{array}$ & 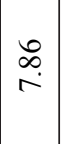 & $\begin{array}{l}\infty \\
\infty \\
\stackrel{0}{0}\end{array}$ & $\begin{array}{c}+ \\
\stackrel{\infty}{*} \\
\dot{r}\end{array}$ & $\mid \begin{array}{l}n \\
\dot{s} \\
\dot{f}\end{array}$ \\
\hline & 띠 & $\infty$ & 点 & $\tilde{F}$ & ? & $\stackrel{+}{-}$ & $\frac{0}{\dot{b}}$ & $\begin{array}{l}0 \\
i \\
i\end{array}$ & ले & $\stackrel{2}{m}$ & 足 & $\mid \begin{array}{l}\infty \\
0 \\
0\end{array}$ & $\ddot{0}$ & $\left|\begin{array}{c}0 \\
\dot{a} \\
-1\end{array}\right|$ & $\begin{array}{l}0 \\
\dot{m}\end{array}$ & $\hat{\varrho}$ & $\vec{m}$ & $\hat{\bar{q}}$ & $\underset{\infty}{\infty}$ & $\stackrel{\infty}{\circ}$ & in & $F$ \\
\hline & - & 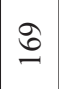 & $\bar{\nabla}$ & $\bar{\delta}$ & $\widehat{6}$ & $\underset{\stackrel{F}{f}}{\stackrel{i}{i}}$ & $\hat{i}$ & $\stackrel{0}{\stackrel{r}{r}}$ & $\stackrel{n}{=}$ & $\tilde{\vartheta}$ & $\vec{D}$ & \begin{tabular}{|c|} 
\\
\multirow{2}{*}{} \\
$\infty$
\end{tabular} & $\mid \begin{array}{l}\vec{\infty} \\
\dot{0}\end{array}$ & $\left|\begin{array}{l}0 \\
i \\
n\end{array}\right|$ & $\begin{array}{l}0 \\
\dot{\gamma} \\
\dot{f}\end{array}$ & 昌 & $\underset{m}{\mathbb{N}}$ & $\underset{\sim}{\sim}$ & $\stackrel{\partial}{\infty}$ & $\stackrel{0}{\circ}$ & $\approx$ & 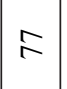 \\
\hline \multirow{3}{*}{$\bar{v}$} & 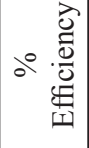 & $\begin{array}{r}\dot{0} \\
\ddot{0}\end{array}$ & $\begin{array}{l}\mathbb{t} \\
\dot{J} \\
\dot{J}\end{array}$ & $\begin{array}{l}\mathbf{d} \\
\stackrel{\sim}{\mathbf{N}}\end{array}$ & $\stackrel{n}{m}$ & $\overrightarrow{\stackrel{T}{+}}$ & $\stackrel{\hat{0}}{\Xi}$ & $\frac{a}{a}$ & 8 & $\stackrel{?}{=}$ & 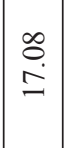 & $\left|\begin{array}{l}0 \\
\pm \\
\pm\end{array}\right|$ & $\begin{array}{l}0 \\
8\end{array}$ & 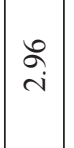 & $\stackrel{m}{m}$ & in & $\begin{array}{l}\stackrel{0}{0} \\
\stackrel{6}{6}\end{array}$ & $\begin{array}{l}\text { : } \\
\stackrel{0}{\circ}\end{array}$ & 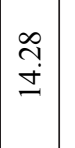 & $\begin{array}{l}n \\
\infty \\
\infty \\
\infty\end{array}$ & 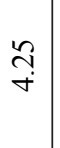 & $\mid \begin{array}{c}\vec{m} \\
\dot{\omega} \\
\dot{\sim}\end{array}$ \\
\hline & 디 & \pm & $\begin{array}{c}\infty \\
m \\
m\end{array}$ & 守 & $\begin{array}{l}\infty \\
\infty\end{array}$ & $\underset{\tilde{O}}{\tilde{-}}$ & $\begin{array}{c}0 \\
i \\
i\end{array}$ & $\begin{array}{l}0 \\
\dot{8} \\
\end{array}$ & $\tilde{\sigma}$ & ¿ & $\begin{array}{c}\tilde{F} \\
\tilde{F}\end{array}$ & $\stackrel{\infty}{\stackrel{1}{r}}$ & $\tilde{O}$ & 足 & $\vec{m}$ & $\infty$ & f & శ్రి & $\stackrel{2}{\sim}$ & $\begin{array}{l}2 \\
0 \\
0 \\
0\end{array}$ & 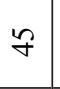 & $\stackrel{\infty}{n}$ \\
\hline & - & હे & §̊ & 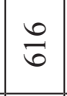 & $\mid \begin{array}{l}n \\
\infty \\
\infty\end{array}$ & $\stackrel{9}{-}$ & $\begin{array}{l}0 \\
\dot{8}\end{array}$ & $\begin{array}{l}0 \\
i \\
i n\end{array}$ & $\stackrel{\mathcal{N}}{-}$ & $\stackrel{?}{m}$ & $\overrightarrow{\widetilde{n}}$ & $\left|\begin{array}{c}\tilde{n} \\
\infty \\
\infty\end{array}\right|$ & $\because n$ & O. & $\stackrel{\sim}{n}$ & 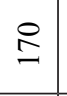 & $\vec{n}$ & 吉 & $\stackrel{+}{\infty}$ & $\begin{array}{l}n \\
\stackrel{2}{0} \\
0\end{array}$ & F & $\vec{\infty}$ \\
\hline & \multirow{2}{*}{ 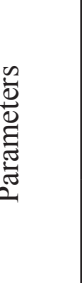 } & $\mid \begin{array}{c}\widehat{\theta} \\
0 \\
\Xi \\
\Xi \\
0 \\
\delta\end{array}$ & 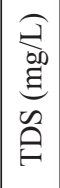 & 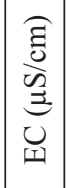 & 蛋 & 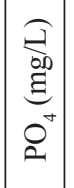 & 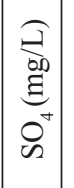 & $\mid \begin{array}{l}\widehat{J} \\
\Delta D \\
\Xi \\
z \\
\exists\end{array}$ & 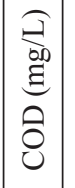 & 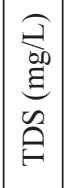 & 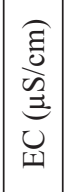 & 志 & 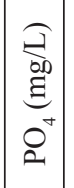 & 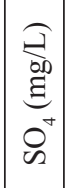 & 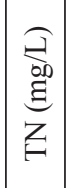 & 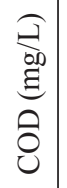 & 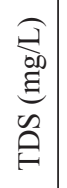 & 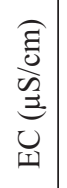 & 丞 & 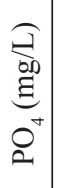 & 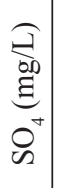 & $\left|\begin{array}{c}\vec{\partial} \\
\overrightarrow{b D} \\
\underline{\Xi} \\
z \\
z\end{array}\right|$ \\
\hline & & & & & & & & & & & & $\stackrel{\vec{\alpha}}{\underline{\underline{\prime}}}$ & & & & & & & & & & \\
\hline
\end{tabular}


Table 2. Overall efficiency of pilot-scale TFs in the average percentage reduction of different physico-chemical parameters under different HRTs.

\begin{tabular}{|c|c|c|c|c|c|c|c|}
\hline \multirow{2}{*}{ HRTs } & \multicolumn{7}{|c|}{ Avg. percentage (\%) reduction in different parameters } \\
\cline { 2 - 9 } & $\mathrm{COD}(\mathrm{mg} / \mathrm{L})$ & $\mathrm{TDS}(\mathrm{mg} / \mathrm{L})$ & $\mathrm{EC}(\mu \mathrm{S} / \mathrm{cm})$ & $\mathrm{pH}$ & $\mathrm{PO}_{4}(\mathrm{mg} / \mathrm{L})$ & $\mathrm{SO}_{4}(\mathrm{mg} / \mathrm{L})$ & $\mathrm{TN}(\mathrm{mg} / \mathrm{L})$ \\
\hline $24 \mathrm{hrs}$ & 69.45 & 15.72 & 18.09 & 8.17 & 44.1 & 12.93 & 11.20 \\
\hline $48 \mathrm{hrs}$ & 70.9 & 21.32 & 23.49 & 8.72 & 40.77 & 18.22 & 24.10 \\
\hline $72 \mathrm{hrs}$ & 61.64 & 34.98 & 13.25 & 9.99 & 81.87 & 36.96 & 66.68 \\
\hline
\end{tabular}

amount of nitrogen in the effluent of a wastewater treatment system facilitates hypertrophication and algal growth and hence depletes the oxygen supply [41]. In the present study, it was observed that during the $1^{\text {st }}$ phase of biological operation, an average reduction of $11.2 \%$ whereas $24.1 \%$ and $66.68 \%$ reduction in $\mathrm{TN}$ concentrations were observed during the $2^{\text {nd }}$ and $3^{\text {rd }}$ phases of biological operations, respectively (for an overview, see Table 2). Furthermore, in the present study the highest percentage reduction, i.e., 20.3, 32.8 and $87.2 \%$ in TN concentrations, were observed at HRTs of 24, 48 and 72 hrs, respectively, which was statistically highly significant $(p=0.003)$, as shown in Fig. 5 . Different researchers have reported that the efficiency of a reactor for removing TN from wastewater largely depends on the ratio of COD to TN concentrations $(\mathrm{COD} / \mathrm{TN})$ along with reactor configuration [32, 42]. Ladu et al. [32] reported more than $75 \% \mathrm{TN}$ removal efficiency in a sequencing batch reactor at a $\mathrm{COD} /$ $\mathrm{TN}$ ratio of greater than 3.9, while Wang et al. [42] reported a $37-41 \%$ reduction in $\mathrm{TN}$ concentration at a $\mathrm{COD} / \mathrm{TN}$ ratio of 7.2 . In the present study, 5.1-20.3\% reduction in $\mathrm{TN}$ concentrations at $\mathrm{COD} / \mathrm{TN}$ ratio of 0.9 were observed at HRT of $24 \mathrm{hrs}$ and during the $2^{\text {nd }}$ phase of operation (HRT of $48 \mathrm{hrs}$ ), 3.1-32.8\% reduction in the concentrations of $\mathrm{TN}$ at $\mathrm{COD} / \mathrm{TN}$ ratio of 1.75 while at HRT of $72 \mathrm{hrs}, 28.4-87.2 \%$ reduction in the concentrations of $\mathrm{TN}$ at $\mathrm{COD} / \mathrm{TN}$ ratio of 2.07 were observed. The subsequent increased in COD/TN ratio with HRT confirmed that the rate of nitrification increased, therefore in order to get optimum function of pilot scale TFs, maximum HRT of $72 \mathrm{hrs}$ would be preferred.

\section{Conclusions}

We concluded from the present study that pilot-scale TFs showed significant efficacy regarding the removal of different physicochemical and microbiological parameters under HRTs of 24, 48 and 72 hrs. About 70.9 and $23.5 \%$ reduction in COD and EC content were observed at HRT of $48 \mathrm{hrs}$, respectively, whereas at HRT of $72 \mathrm{hrs}$ the performance efficiency of pilotscale TFs increased significantly in order to reduce different physicochemical parameters, i.e., TDS (34\%), $\mathrm{SO}_{4}(37 \%), \mathrm{PO}_{4}(81.8 \%)$ and $\mathrm{TN}(66.6 \%)$. Furthermore, it was concluded that the efficiency of stone media pilot-scale TFs in terms of pathogen removal (CFU/mL) increased significantly with continuous recirculation of wastewater for an extended period of time. Moreover, stone as natural filter media showed proficiency at pilot-scale operations, thus stone media pilot scale TFs could be a promising and favorable technology for the treatment of wastewater - especially in water-stressed countries.

\section{Acknowledgments}

This research work was part of a project titled "Small-Scale Sewage Treatment and Wastewater Reuse System for Pakistan" and funded by the Higher Education Commission of Pakistan under the PakistanU.S. Science and Technology cooperation program Phase 4 projects [grant No. 4-428].

\section{Conflict of Interest}

The authors declare no conflict of interest.

\section{References}

1. PINTO U., MAHESHWARI B.L., GREWAL H.S. Effects of greywater irrigation on plant growth, water use and soil properties. Resour Conserv Recycl. 54 (7), 429, 2010.

2. SALMA S., SHAH M.A., REHMAN S. Rainfall trends in different climate zones of Pakistan. Pak J Meteorol. 9 (17), 2012.

3. ALKHAMISI S.A., AHMED M. Opportunities and challenges of using treated wastewater in agriculture. In Environmental Cost and Face of Agriculture in the Gulf Cooperation Council Countries. 109-123, 2014.

4. WHO. Progress on sanitation and drinking water: 2015 update and MDG assessment. World Health Organization, 2015.

5. QURESHI A.S. Water management in the Indus basin in Pakistan: challenges and opportunities. Mt Res Dev. 31 (3), 252, 2011.

6. RAZA M., HUSSAIN F., LEE J.Y., SHAKOOR M.B., KWON K.D. Groundwater status in Pakistan: A review of contamination, health risks, and potential needs. Crit. Rev. Environ Sci Technol. 47 (18), 1713, 2017.

7. PEREIRA A.S., CEREJEIRA M.J., DAAM M.A. Comparing ecotoxicological standards of plant protection 
products potentially toxic to groundwater life with their measured and modelled concentrations. Ecotoxicol Environ Saf Abbreviation. 102, 152, 2014.

8. USEPA. Guidelines for Water Reuse. United State Environmental Protection Agency, Washington, DC, 2012.

9. AWAN U.K., ANWAR A., AHMAD W., HAFEEZ M. A methodology to estimate equity of canal water and groundwater use at different spatial and temporal scales: a geo-informatics approach. Environ Earth Sci. 75 (5), 409, 2016.

10. ALI I., HADI F., BANO A. Microbial assisted phytoextraction of metals and growth of soybean (Glycine max L. merrill) on industrial waste water contaminated soil. Pak J Botany. 44 (5), 1593, 2012.

11. FINK R., ODER M., RANGUS D., RASPOR P., BOHINC K. Microbial adhesion capacity. Influence of shear and temperature stress. Int J Environ Health. Res. 25 (6), 656, 2015.

12. LOUPASAKI E., DIAMADOPOULOS E. Attached growth systems for wastewater treatment in small and rural communities: a review. J Che Technol Biotechnol. 88 (2), 190, 2013

13. MAHMOUD M., TAWFIK A., EL-GOHARY F. Simultaneous organic and nutrient removal in a naturally ventilated biotower treating presettled municipal wastewater. J Environ Eng. 136 (3), 301, 2010.

14. NAZ I., ULLAH W., SEHAR S., REHMAN A., KHAN Z.U., ALI N., AHMED S. Performance evaluation of stone-media pro-type pilot-scale trickling biofilter system for municipal wastewater treatment. Desalin Water Treat. 57 (34), 15792, 2016.

15. XIANG Y., SHAO Z., KANG W., ZOU B., CHAI H. Effect of biofilm density on nitrous oxide emissions and treatment efficiency on sequencing batch biofilm reactor. Wat Air Soil Pollut. 227 (9), 304, 2016.

16. LADU J.L., LÜ X.W. Effects of hydraulic retention time, temperature, and effluent recycling on efficiency of anaerobic filter in treating rural domestic wastewater. Water Sci Eng. 7 (2), 168, 2014.

17. KHAN Z.U., NAZ I., REHMAN A., RAFIQ M., ALI N., AHMED S. Performance efficiency of an integrated stone media fixed biofilm reactor and sand filter for sewage treatment. Desalin Water Treat. 54 (10), 2638, 2015.

18. REHMAN A., NAZ I., KHAN Z.U., RAFIQ M., ALI N., AHMAD S. Sequential application of plastic mediatrickling filter and sand filter for domestic wastewater treatment at low temperature condition. Br Biotechnol J. 2 (4), 179, 2012.

19. LUOSTARINEN S., SANDERS W., KUJAWAROELEVELD K., ZEEMAN G. Effect of temperature on anaerobic treatment of black water in UASB-septic tank systems. Bioresour Technol. 98 (5), 980, 2007.

20. SEGHEZZO L. Anaerobic Treatment of Domestic Wastewater in Subtropical Regions. Dissertation, Wageningen University, 2004.

21. DAIJA L., SELBERG A., RIKMANN E., ZEKKER I., TENNO T., TENNO T. The influence of lower temperature, influent fluctuations and long retention time on the performance of an upflow mode laboratory-scale septic tank. Desalin Water Treat. 57 (40), 18679, 2016.

22. RASOOL T., REHMAN A., NAZ I., ULLAH R., AHMED S. Efficiency of a locally designed pilot-scale trickling biofilter (TBF) system in natural environment for the treatment of domestic wastewater. Environ Technol. 39 (10), 1295, 2018.
23. APHA. Standard methods for the examination of water and wastewater. American Public Health Association/ American Water Works Association/Water Environment Federation, Washington DC, USA, 2005.

24. HAMID H., ESKICIOGLU C. Fate of estrogenic hormones in wastewater and sludge treatment: A review of properties and analytical detection techniques in sludge matrix. Water Res. 46 (18), 5813, 2012.

25. PERUJO N., ROMANÍ A.M., SANCHEZ-VILA X. Bilayer infiltration system combines benefits from both coarse and fine sands promoting nutrient accumulation in sediments and increasing removal rates. Environ Sci Technol. 52 (10), 5734, 2018.

26. PURNELL S., EBDON J., BUCK A., TUPPER M., TAYLOR H. Removal of phages and viral pathogens in a full-scale MBR: implications for wastewater reuse and potable water. Water Res. 100, 20, 2016.

27. WHO. Guidelines for the safe use of wastewater, excreta and greywater (Vol. 1). World Health Organization, 2006.

28. LEONARD A. Management of wastewater sludge's: a hot topic at the European level. J Residu Sci Technol. 8 (2), 2011.

29. LUCAS F.S., THERIAL C., GONÇALVES A., SERVAIS P., ROCHER V., MOUCHEL J.M. Variation of raw wastewater microbiological quality in dry and wet weather conditions. Environ Sci Pollut Res. 21 (8), 5318, 2014.

30. RAJAKUMAR R., MEENAMBAL T., BANU J.R., YEOM I.T. Treatment of poultry slaughterhouse wastewater in up flow anaerobic filter under low up flow velocity. Int J Environ Sci Technol. 8 (1), 149, 2011.

31. LUIZ A., HANDELSMAN T., BARTON G., COSTER H., KAVANAGH J. Membrane treatment options for wastewater from cellulosic ethanol bio refineries. Desalin Water Treat. 53 (6), 1547, 2015.

32. LADU J.L.C., LU X.W., OSMAN A.M. Integrated Processes of Anoxic/Oxic Bioreactor and Artificial Wetland for Rural Domestic Wastewater Treatment. Adv Mat Res. (955), 2526, 2014.

33. LAING $\mathrm{M}$. Investigating the performance of a novel Anaerobic Sequencing Batch Reactor (AnSBR) and optimization of operational parameters to treat synthetic winery wastewater (Doctoral dissertation, Stellenbosch: Stellenbosch University), 2016.

34. LEYVA-DÍAZ J.C., MUÑÍO M.M., GONZÁLEZ-LÓPEZ J., POYATOS J.M. Anaerobic/anoxic/oxic configuration in hybrid moving bed biofilm reactor-membrane bioreactor for nutrient removal from municipal wastewater. Ecol Eng. 91, 449, 2016

35. FERNANDES P.M., PEDERSEN L.F., PEDERSEN P.B. Influence of fixed and moving bed biofilters on micro particle dynamics in a recirculating aquaculture system. Aquacult Eng. 78, 32, 2017.

36. SHI J., PODOLA B., MELKONIAN M. Removal of nitrogen and phosphorus from wastewater using microalgae immobilized on twin layers: an experimental study. J Appl Phycol. 19 (5), 417, 2007.

37. ZENG R.J., YUAN Z., KELLER J. Enrichment of denitrifying glycogen-accumulating organisms in anaerobic/anoxic activated sludge system. Biotechnol Bioeng. 81 (4), 397, 2003.

38. EHLERS G.C., TURNER S. Biofilms in wastewater treatment systems. Microbial Biofilms-Current Research and Applications, 99, 2012.

39. USEPA. Bureau of water supply and wastewater management: department of environmental protection 
agency, wastewater treatment plant operator training. United State Environmental Protection Agency, 2007.

40. GANGAL M., KALDATE A., GRAVELEAU L., DESMOTTES C. Evaluation of Low Energy Requirements in Deammonification Systems. Proceedings of the Water Environment Federation. 2, 1, 2015.

41. SAKUMA T., JINSIRIWANIT S., HATTORI T., DESHUSSES M.A. Removal of ammonia from contaminated air in a biotrickling filter-denitrifying bioreactor combination system. Water Res. 42 (17), 4507, 2008.

42. WANG H., ZHI W., DENG N., JI G. Review on the Fate and Mechanism of Nitrogen Pollutant Removal from Wastewater Using a Biological Filter. Pol J Environ Stud. 26 (5), 2017. 
